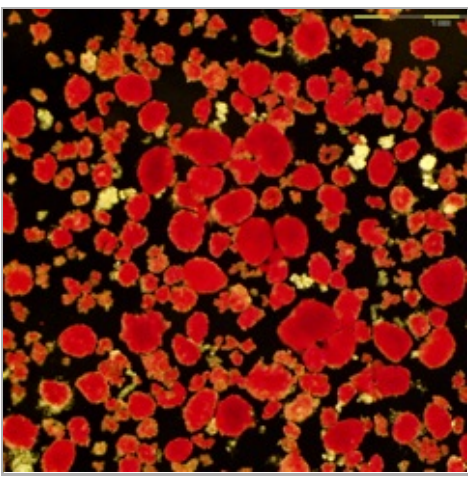

\section{VERSION 2}

\section{APR 30, 2021}

\section{open $\mathcal{O}$ access}

\section{DOI:}

dx.doi.org/10.17504/protocol s.io.bt6cnraw

\section{Protocol Citation: James} Lyon, Aliya F Spigelman, Jocelyn E Manning Fox, Patrick E Macdonald 2021. Human Islet Cryopreservation Version 2.0. protocols.io https://dx.doi.org/10.17504/p rotocols.io.bt6cnrawVersion created by Jocelyn E Manning Fox

License: This is an open access protocol distributed under the terms of the Creative Commons Attribution License, which permits unrestricted use, distribution, and reproduction in any medium, provided the original author and source are credited

\section{Protocol status: Working} We use this protocol and it's working

\section{Created: Apr 12, 2021}

Last Modified: Apr 30, 2021

\section{(3) Human Islet Cryopreservation Version 2.0 V.2}

James Lyon ${ }^{1}, \quad$ Aliya F Spigelman ${ }^{1}$, Jocelyn E Manning Fox ${ }^{1}$, Patrick E Macdonald ${ }^{1}$

${ }^{1}$ University of Alberta

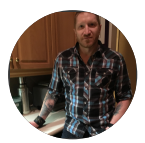

James Lyon

University of Alberta

\section{ABSTRACT}

This protocol details the cryopreservation of human islets, as performed by the Alberta Diabetes Institute IsletCore. Human islets cryopreserved using this method have been found to retain viability and function after 20 years of cryogenic biobanking.

Manning Fox JE, Lyon J, Dai XQ, Wright RC, Hayward J, van de Bunt M, Kin T, Shapiro AMJ, McCarthy MI, Gloyn AL, Ungrin MD, Lakey JR, Kneteman NM, Warnock GL, Korbutt GS, Rajotte RV, MacDonald PE (2015) Human islet function following 20 years of cryogenic biobanking. Diabetologia, 58(7): 1503-1512.

\section{MATERIALS}

\section{MATERIALS}

88 Cryopreservation storage tubes (12ml) Thermo Scientific Catalog \#3775

\section{DMSO Fisher Scientific Catalog \#BP231}

Sodium bicarbonate Fisher Scientific Catalog \#S233-

88500

88 HEPES Fisher Scientific Catalog \#BP310-1

88 Penicillin/Streptomycin Lonza Catalog \#09-757F

89 M199 medium Fisher Scientific Catalog

88 \#MT90050РB

Brady FREEZERBONDZ Polyester thermal transfer printer labels Fisher

88 Scientific Catalog \#22-500521

88 HyClone Fetal Bovine Serum Fisher Scientific Catalog \#SH3039603

88 Syringe Filters Nylon 0.2 $\mu \mathrm{m}$ pore Sterile Fisher Scientific Catalog \#N7262520

FTS Multi Cool low temperature bath LabWrench Catalog 88 \#MC880

PROTOCOL integer ID: 49060 


\section{Preparation of Solutions}

M199 Media Preparation Table

\begin{tabular}{|l|l|l|l|l|}
\hline A & B & C & D & E \\
\hline M199 (10L) & Concentration & Weight/Volume & Supplier & Catalogue \# \\
\hline M199 powder & $9.41 \mathrm{~g} / \mathrm{L}$ & 1 bottle & $\begin{array}{l}\text { Mediatech- } \\
\text { Corning }\end{array}$ & 90050PB 3 \\
\hline NaHCO3 & $26 \mathrm{mM}$ & $22.0 \mathrm{~g}$ & $\begin{array}{l}\text { Fisher } \\
\text { Scientific }\end{array}$ & S233-500 \\
\hline HEPES & $10 \mathrm{mM}$ & $23.83 \mathrm{~g}$ & $\begin{array}{l}\text { Fisher } \\
\text { Scientific }\end{array}$ & BP310-1 \\
\hline Penicillin/Streptomycin & $\begin{array}{l}20,000 \mathrm{U} / \mathrm{ml} \\
\text { penicillin and } \\
20,000 \mu \mathrm{g} / \mathrm{ml} \\
\text { streptomycin }\end{array}$ & $50 \mathrm{ml}$ & Lonza & 09-757F \\
\hline
\end{tabular}

Prepare the M199 solution using the above Media Preparation table above:

1. Dispense $\triangle 9 \mathrm{~L}$ of Milli-Q $(18 \mathrm{~m} \Omega)$ water in to a carboy

2. Store overnight at $8^{\circ} 4^{\circ} \mathrm{C}$ to allow to come to temperature.

3. Using a stirrer add the M199 media powder to the water and allow to mix into solution.

4. Add the powdered supplements and Penicillin/Streptomycin to the appropriate media based on the above table and allow to stir into solution.

5. Stir the solution for 00:30:00

6. Store the prepared solution overnight at $8^{\circ} 4^{\circ} \mathrm{C}$ to allow all powders to go into solution

7. Stir the solution for $00: 30: 00$

8. Calibrate the $\mathrm{pH}$ meter using the $\mathrm{pH}$ control buffers

9. Adjust the $\mathrm{pH}$ level of $\mathrm{M} 199$ solution to 7.4 using the $\mathrm{NaOH}$ and/or $\mathrm{HCl}$.

10. Bring to volume of $\triangle 10 \mathrm{~L}$ with the appropriate amount of Milli-Q water $(18 \mathrm{~m} \Omega)$.

Filter into $\triangle 1 \mathrm{~L}$ bottles with a $0.22 \mu \mathrm{m}$ nitrocellulose filter. 


\section{Freeze M199:}

Prepare Freeze M199 solution as follows:

Add \ $100 \mathrm{~mL}$ heat inactivated FBS (HyClone ${ }^{\text {Tw }}$ Fetal Bovine Serum (Canada), Characterized Fisher cat\# SH3039603) to \& $900 \mathrm{~mL}$ M199 media.

\section{Store at $8^{\circ} 4^{\circ} \mathrm{C}$}

Warm to room temperature prior to use.

Heat inactivation of FBS

1. Thaw serum and aliquot into labelled $50 \mathrm{ml}$ tubes. If serum was thawed in a refrigerator allow serum to come to room temperature prior to placing in water bath.

2. Fill the water-bath with sufficient water so that the tubes may be submersed to the level of the serum.

3. Set water-bath temperature to maintain the product at $8^{\circ} 56^{\circ} \mathrm{C}$

4. Once $8^{\circ} 56^{\circ} \mathrm{C}$ is reached, place the tubes in the water-bath for (1) 00:30:00

5. After 30 minutes immediately remove the tubes from the water bath.

6. Store the tubes of heat inactivated FBS at $8^{\circ}-20^{\circ} \mathrm{C}$

\section{2M DMSO:}

- Add Freeze M199 to

(Fisher Scientific - Cat\# BP231)for a total volume of $50 \mathrm{ml}$.

- Filter sterilize through a syringe filter (Nylon $0.2 \mu \mathrm{m}$ pore) into a sterile glass media bottle

- Store at $84^{\circ} \mathrm{C}$.

- Warm to room temperature prior to use.

\section{3M DMSO:}

- Add Freeze M199 to volume of $50 \mathrm{ml}$.

- Filter sterilize through a syringe filter (Nylon $0.2 \mu \mathrm{m}$ pore) into a sterile glass media bottle.

- Store at $8^{\circ} 4^{\circ} \mathrm{C}$

- Warm to room temperature prior to use. 


\section{Pre-cool cryopreservation bath}

5 Pre-cool FTS bath and set temperature at $8^{\circ}-7.4^{\circ} \mathrm{C}$ starting temp approximately

02:00:00 prior beginning the cryopreservation.

\section{Label the cryopreservation tubes}

6 Label cryopreservation tubes using Brady ${ }^{\text {TM }}$ FREEZERBONDZ ${ }^{\text {TM }}$ Polyester Thermal Transfer Printer Labels (Fisher Scientific Cat \#22-500521). Include the following information.

- Internal Identifier number (Rxxx)

- Number of islet equivalents (IEQ) per tube

- Cryoprotectant (DMSO)

- Cryopreservation date

- Tube number

\section{Protocol}

7 Aliquot islets into the cryopreservation tubes with a maximum of 25,000 IEQ per cryopreservation tube.

$8 \quad$ Centrifuge all tubes

$$
\because \begin{aligned}
& 280 \times \mathrm{g}, 4^{\circ} \mathrm{C} \\
& 00: 01: 00
\end{aligned}
$$

After centrifugation, remove the supernatant.

9 At room temperature, add $\Delta 1 \mathrm{~mL}$ of freeze M199 to each tube and suspend the islets.

$$
8^{\circ} 22^{\circ} \mathrm{C}
$$


10

At room temperature, add $\triangle 500 \mu \mathrm{L} 2 \mathrm{M}$ DMSO and start timer.

\section{$8^{\circ} 22^{\circ} \mathrm{C} \quad 00: 00: 00$}

11 At 5 minutes add an additional $\triangle 500 \mu \mathrm{L}$ 2M DMSO.

$$
822^{\circ} \mathrm{C}
$$

12 At 30 minutes add $82 \mathrm{~mL} 3 \mathrm{M}$ DMSO.

$$
8^{\circ} 22^{\circ} \mathrm{C}
$$

13 At 45 minutes transfer all tubes to a rack in an ice bath.

${ }^{8 .} 0^{\circ} \mathrm{C}$ ice

14 At 55 minutes transfer all tubes to the pre-chilled FTS bath $\left(-7.5^{\circ} \mathrm{C}\right)$

$$
8^{8}-7.5^{\circ} \mathrm{C} \text { Seeding }
$$

15 At 65 minutes nucleate* all tubes to release the latent heat of fusion

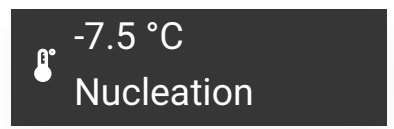

*Nucleation is necessary to remove the latent heat of fusion. At this point the tissue suspension is "super-cooled". This refers to the fact that the suspension is liquid despite being at $-7.5^{\circ} \mathrm{C}$. Nucleation is achieved by submersing each tube for 2 seconds in liquid nitrogen and then applying a mechanical force (firmly hit the tube against a solid object). If nucleation is successful the solution will appear to be a "slush". Immediately after nucleation return each tube back to the seeding bath.

16 At 85 minutes begin the FTS bath rate cooling procedure at $2.5^{\circ} \mathrm{C} / \mathrm{min}$ 


\section{$-7.5^{\circ} \mathrm{C}$ cool down by}

$2.5^{\circ} \mathrm{C} / \mathrm{min}$

17 Once the FTS bath reaches $8^{\circ}-40^{\circ} \mathrm{C}$ all tubes can be transferred to liquid nitrogen

\section{Storage}

18 Once the cryopreservation protocol is complete and the tubes have been transferred to liquid nitrogen $\left(-190^{\circ} \mathrm{C}\right)$, the tubes can be transferred to long term storage in a liquid nitrogen vapour phase. This vapour phase can be achieved by using a Chart MVE 1500 Series $\mathrm{LN}_{2}$ storage tank or similar system.

\section{$-190{ }^{\circ} \mathrm{C}$ store in $\mathrm{LN} 2$ vapour}

$8^{\circ}$

phase

Human islets cryopreserved in this manner can be successfully thawed using the Thawing Cryopreserved Human Islets protocol. 